\title{
Acupuncture as Adjuvant Therapy in Thalamic Syndrome: Case Report
}

\author{
Alysson Bruno Oliveira Santos ${ }^{1}$, Judymara Lauzi Gozzani, TSA²
}

Summary: Santos ABO, Gozzani JL - Acupuncture as Adjuvant Therapy in Thalamic Syndrome: Case Report.

Background and objectives: Cerebrovascular diseases are responsible for a large proportion of deaths in the world. Among survivors, the majority of limiting sequelae observed is motor in origin; but when sensorial pathways or centers are affected patients can evolve with sensorial changes in the body region represented by the area of the brain affected. When the affected area is related to the thalamus the patient might develop thalamic syndrome. The objective of this report was to demonstrate the use of electroacupuncture as adjuvant in the treatment of central pain, diagnosed as thalamic syndrome difficult to control with pharmacologic therapy.

Case report: This is a 46 year-old female with history of ischemic stroke in the left temporoparietal region in April 2003 that evolved to right hemiparesis and hemitaxia. One year later, the patient developed continuous, insidious pain on the right side of the body with allodynia and hyperalgia, diagnosed as thalamic syndrome. In January 2006, she was admitted to the department of pain therapy and palliative care of Santa Casa de Misericórdia de São Paulo where pharmacologic treatment was instituted with poor response; she was scheduled for neurofunctional surgery. In July 2009, electroacupuncture, in an attempt to obtain better pain control, was proposed to the patient. Electroacupuncture was done on points in the scalp. After the $11^{\text {th }}$ session, her pain was controlled, with no use of opioids or topical amitriptyline, her well-being had increased, her motor coordination improved, she presented global pain reduction, complete in hand and face.

Conclusions: The efficacy of electroacupuncture in pain control and well-being are in agreement with modern studies which demonstrated activation of antinociceptive pathways in the brain. Controlled prospective studies are required to reaffirm and consolidate electroacupuncture as an important technique in controlling central pain.

Keywords: Acupuncture Analgesia; Electroacupuncture; Pain; Stroke.

[Rev Bras Anestesiol 2011;61(1): 88-94] @Elsevier Editora Ltda.

\section{INTRODUCTION}

Cerebrovascular diseases are responsible for the majority of deaths in the world. The annual incidence estimated in most populational studies is between 300 and 500 per 100 thousand people. In Brazil, this reality is not different. In 2005, it showed a mortality of 87,344 patients, surpassing coronariopathies. Up to $90 \%$ of survivors have some type of deficiency, which can lead to personal and social limitations and economic downfall, since many patients are below 65 years of age ${ }^{1,2,3}$. Most limiting sequelae observed are motor in origin; but when sensorial pathways and centers are affected, patients can evolve with sensorial changes in the area of the body corresponding to the affected area of the brain. When that area is related with the thalamus, thalamic syndrome might follow. This is characterized by rapidly progressive hemiparesis; persistent superficial hemianesthesia or hemi-hyperesthesia;

Received from the Department of Pain and Palliative Care of Santa Casa de Misericórdia de São Paulo, Brazil.

1. Anesthesiologist Specialist in Pain at SBA; Acupuncture Specialist at CMBA

2. PhD in Medicine from Unifesp, Co-responsible for the CET/SBA of SCSP; Coordinator of

the Pain Department of SCSP

Submitted on June 28, 2010.

Approved on July 27, 2010.

Correspondence to:

Dr. Alysson Bruno Oliveira Santos

Av. Chibarás, 44/1.301

Planalto Paulista

040976-000 - São Paulo, SP, Brazil

E-mail: alyssonbruno@hotmail.com marked deep sensorial changes; subtle hemiataxia and asterognosia; severe, persistent, paroxysmal pain usually unbearable and that does not respond to traditional analgesic treatment; and ipsilateral coreoatetosis ${ }^{4}$. The treatment used most often is based on rehabilitation with physiotherapy, use of pharmacologic arsenal, psychotherapy, sympathetic or peripheral nerve blocks, peripheral or central electric stimulation, laser, and acupuncture ${ }^{5}$.

The objective of this report was to demonstrate the use of electroacupuncture as adjuvant in the treatment of central pain, diagnosed as thalamic syndrome difficult to control with pharmacologic treatment.

\section{CASE REPORT}

This is a 46 years old female, weighing $53 \mathrm{~kg}$, smoker, with history of ischemic stroke in the left temporoparietal region in April 2003 (Figures 1 and 2) who evolved with right hemiparesis and hemitaxia. One year later she developed insidious, continuous diffuse pain affecting the right side of her body, along with allodynia and hyperalgia that evolved to severe, difficult to control pain which was later diagnosed as thalamic syndrome. The patient had intermittent frequently worsening of the pain spontaneous or secondary to emotions (fear, happiness, sadness, worry). During this period, the patient developed depression and panic attacks, which hindered even more her functionality and socialization. In January 2006, the patient was admitted to the pain therapy and palliative 
medicine of Santa Casa de Misericórdia de São Paulo where she was treated uninterruptedly by psychiatry and neurosurgery. In 2009, she was receiving Gabapentin 400 mg every 8 hours, Fluoxetine $60 \mathrm{mg}$ in the morning, Clonazepam $1 \mathrm{mg}$ at bedtime, Talniflumate, Pentoxifylline, rescue Codeine ( 3 times a day), and $2 \%$ amitriptyline ointment to be applied in areas of increased allodynia. Even with this medication she complained that her pain was not under control, which caused

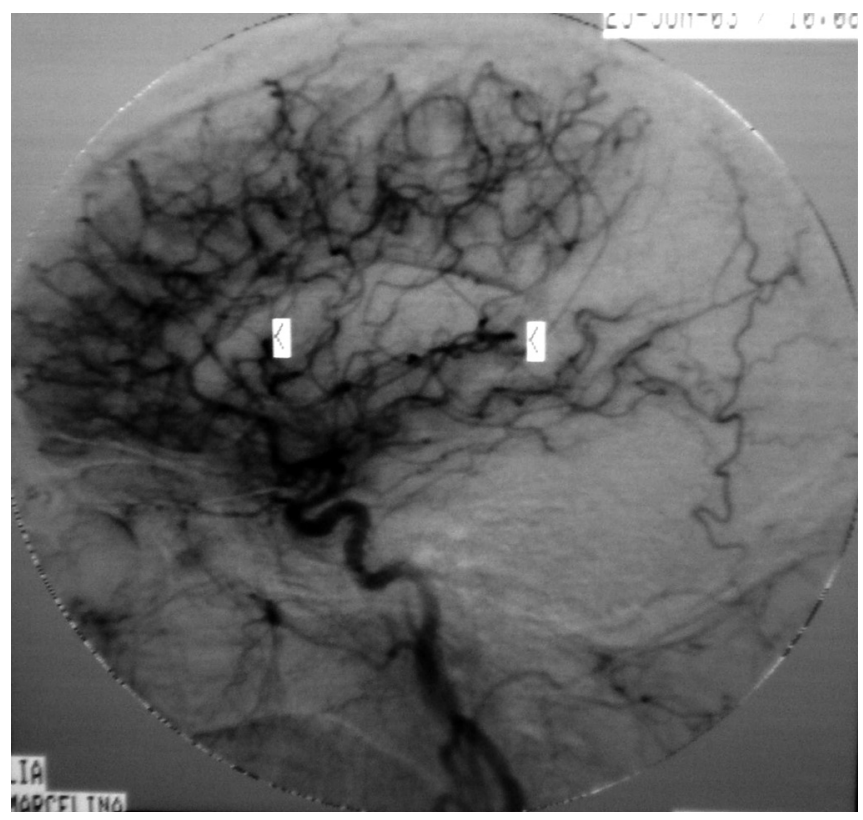

Figure 1 - Cerebral Angiography Showing Relatively Localized Occlusions of Secondary Intracranial Branches, Suggesting Embolus (06/25/03).

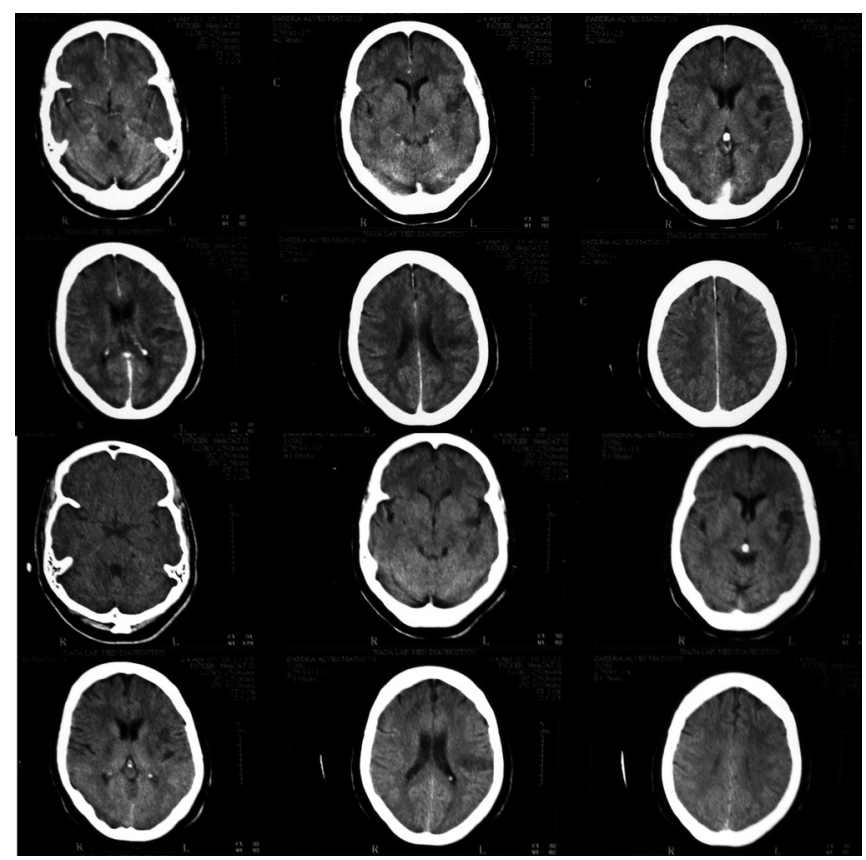

Figure 2 - CT Scan Demonstrating a Left Temporoparietal Hypodense Irregular Area, Compatible with Ischemic Lesion (04/24/03). great limitations in daily activities, sleep, and social life. She had constant episodes triggered by emotions. A magnetic resonance imaging (MRI) showed focal lesions in angular and supramarginal gyri, long insular gyri, and non-specific hypersignal foci in periventricular white matter and semioval centers (Figure 3). In another attempt to control her pain, the functional neurosurgery department scheduled the patient to undergo implantation of a neurostimulator, but they were still waiting for a bed.

In July 2009 the use of electroacupuncture was proposed to the patient in an attempt to improve pain control while she waited for the implant. The patient agreed and weekly sessions were scheduled. Each session was composed of two steps. The first, electroacupuncture, with frequency of $8 \mathrm{~Hz}$ in YNSA points and motor, sensorial, and vasodilation lines of classical scalp electroacupuncture (scalp step). In the second step, the patient underwent classical systemic acupuncture with some of those points stimulated by mixed frequency of 2 and $100 \mathrm{~Hz}$ (points IG4 - TA 5, and BP6 E40) for 20 minutes (systemic step). In the first five sessions, to avoid increasing her pain, acupuncture needles were applied only to the left side of the patient (healthy side). In the remainder sessions, the needles were successfully applied to both sides of her body. From the eighth session on, the first step was maintained, changing the points stimulated by electroacupuncture along with the frequency of the second step (systemic step) that was changed to continuous strengthening wave of $2 \mathrm{~Hz}$ in points IG4 - IG10, P3 - TA5, E36 - BP10, and VB34 - B59 on the right side for 20 minutes. In all sessions, data like pain severity, evaluated by the visual analogue scale, use of rescue medication, evolution during the week, and verbal scale quantifying well-being, were collected. The patient underwent 11 sessions of acu-



Figure 3 - MRI Showing Focal Lesions in Angular, Supramarginal, and Long Insula Gyri, as well as Non-specific Foci of Hypersignal in Periventricular White Matter and Semioval Centers (04/25/09). 
puncture, without interruptions, and she was scheduled for maintenance treatment to increase pain control.

The patient referred improvement of her pain, increase well-being and sleeping almost discontinuing the rescue opioid (codeine) and use of topical amitriptyline since the first session, which was continuous and progressive. After the third session, she showed a significant reduction of allodynia and hyperalgia in the palm of her hand, which stimulated her to start several routine manual activities and improved her social life, and she did not require rescue medication or topical amitriptyline. After the fifth session, she referred improved control of movements of her right hand and foot, elevated well-being, better control of emotion-triggered crisis, and higher motivation. She had started to exercise more, increased the variety of daily activities, and became more independent. After the $11^{\text {th }}$ session her pain was controlled without opioids and topical amitriptyline (since the second week of treatment), her well-being had increased, she showed reduction of paresia, and improved motor coordination. She said she would like to continue the treatment and was thinking about postponing the neurosurgical procedure.

\section{DISCUSSION}

The first descriptions of central pain as a consequence of strokes date back to the mid XIX Century. In 1983, Greiff made the first complete description of central pain in which he evaluated a patient with constant pain secondary to a brain lesion that included the thalamus. In 1906, Dejerine and Roussy described the clinical characteristics of thalamic syndrome, which was named after both authors ${ }^{4}$. Luckily, complete thalamic syndrome is rare. Treatment is based on rehabilitation with physiotherapy, drugs, psychotherapy, sympathetic or peripheral nerve blocks, peripheral or central electrical stimulation, laser, and acupuncture. Among the drugs used are anticonvulsants (carbamazepine, oxcarbazepine, gabapentin, clonazepam), antidepressants (amitriptyline, nortriptyline, imipramine, fluoxetin, sertraline, venlafaxine), neuroleptics (chlorpromazine, periciazine), muscle relaxants (baclofen, cyclobenzaprine), and opioids (codeine, tramadol, methadone) ${ }^{5}$.
Electroacupuncture was first used in China in the decade of 1930. It was investigated more seriously from the decade of 1950 on, along with the development of acupuncture for anesthesia, and became popular in the decade of 1970. Today, it is widely used to treat pain and physical disorders, as well as inducing analgesia in surgical procedures ${ }^{6}$. Several studies of different medical areas widened the use of this technique in several specialties. Electroacupuncture consists of electrical stimulation of a specific frequency through needles inserted in classical acupuncture points or microsystems (scalp acupuncture, auriculoacupuncture, or Yamamoto new scalp acupuncture). Chinese scalp acupuncture was developed at the end of the decade of 1960 and unlike classic acupuncture it does not use acupuncture points or meridians; the needles are inserted in the scalp looking for correspondence for cortical functional areas ${ }^{6-8}$. Yamamoto New Scalp Acupuncture (YNSA) was developed in 1970 and published in 1973, in the $25^{\text {th }}$ meeting of the Japanese Society of Ryodoraku, in Osaka, Japan. Yamamoto new scalp acupuncture is a somatotopic acupuncture. According to this technique, it is believed that the body has representation in small predetermine areas of the scalp, which are punctured to achieve results in the represented areas ${ }^{8}$.

The efficacy of the treatment in controlling pain and increasing well-being in the case reported here is in agreement with current studies using functional magnetic resonance imaging that demonstrated that electroacupuncture stimuli in specific points (IG4, E36, VB34) activate structures of the antinociceptive pathways (hypothalamus, accumbens nucleus, primary somatic sensory-motor cortex, anterior insula, middle cingulate cortex, pontine raphe), inactivate multiple limbic areas involved in pain connections (rostral anterior cingulate cortex, amygdala, and hippocampal complex), suggesting the importance of the adjunct treatment of central pain with electroacupuncture..$^{9-13}$ The release of several neurotransmitters induced by electroacupuncture, such as endorphins, enkephalins, dinorphins, serotonin, and norepinephrine has been associated to its analgesia effect ${ }^{13}$. A controlled study with YNSA points showed a significant difference in controlling induced pain in the calcaneus when compared to placebo, showing the analgesic efficacy of the technique ${ }^{8,14}$. However, controlled prospective studies are necessary to consolidate electroacupuncture as an important tool in the control of central pain. 


\section{REFERÊNCIAS / REFERENCES}

01. Lotufo PA - Stroke in Brazil: a neglected disease. São Paulo Med J, 2005;123:3-4

02. Lotufo PA - Mortalidade pela doença cerebrovascular no Brasil. Rev Bras Hipertens, 2000;7:387-391.

03. Makiyama TY, Battisttella LR, Litvoc $\mathrm{J}$ et al. - Estudo sobre a qualidade de vida de pacientes hemiplégicos por acidente vascular cerebral e de seus cuidadores. Acta Fisiátrica, 2004;11:106-109.

04. Amâncio EJ, Teixeira MJ - Dor por lesão encefálica. Rev Med (São Paulo), 1999;78:208-223.

05. Sakata RK, Issy AM - Guia de Dor. $2^{\underline{a}}$ Ed, Barueri, Manole, 2008;95-105. 
06. Altman S - Técnicas e Instrumentação, em: Schoen AM - Acupuntura Veterinária da Arte Antiga à Medicina Moderna. $2^{\underline{a}}$ ed., São Paulo, Roca, 2006;91-108.

07. Yamamura $Y$ - Acupuntura Tradicional: Arte de Inserir. $2^{\underline{a}}$ ed., São Paulo, Roca, 2001;657- 662; 705-716.

08. Yamamoto T, Yamamoto H, Yamamoto MM - Nova Craniopuntura de Yamamoto, NCY. São Paulo, Roca,2007;1-139.

09. Wu MT, Hsieh JC, Xiong J et al. - Central nervous pathway for acupuncture stimulation: localization of processing with functional MR imaging of the brain - preliminary experience. Radiology, 1999;212:133-141.

10. Wu MT, Sheen JM, Chuang KH et al. - Neuronal specificity of acupuncture response: a fMRI study with electroacupuncture. Neuroimage, 2002; 16:1028-1037.

11. Napadow V, Makris N, Liu J et al. - Effects of electroacupuncture versus manual acupuncture on the human brain as measured by fMRI. Hum Brain Mapp, 2005;24:193-205.

12. Wang W, Liu L, Zhi X et al. - Study on the regulatory effect of electroacupuncture on hegu point (LI4) in cerebral response with functional magnetic resonance imaging. J Integrat Med, 2007;13:10-16.

13. Ma Y, Ma M, Cho ZH - Acupuntura para Controle da Dor: um enfoque integrado. São Paulo, Roca, 2006;49-66; 297- 305.

14. Ogal HP, Hafer J, Ogal M et al. - Veranderungen der Schmerzempfindung bei der Akupunktur eines klassischen Akupunkturpunktes versus eines Schadelakupunkturpunktes nach Yamamoto - Eine prospektiv randomisierte, placebo-kontrollierte Einfachblindstudie. Anasthesiol Intensivmed Notfallmed Schmerzther, 2002;37:326-332.

Resumen: Santos ABO, Gozzani JL - La Acupuntura como Tratamiento Coadyuvante en el Síndrome Talámico: Relato de Caso

Justificativa y objetivos: Las enfermedades cerebrovasculares son las responsables de una gran parte de las muertes en todo el mundo. Entre los sobrevivientes, la mayoría de las secuelas limitantes encontradas en los pacientes es motora, pero cuando se afectan vías o centros sensitivos, los pacientes pueden evolucionar con alteraciones de sensibilidad en la región corporal representada por el área encefálica afectada. Cuando la región acometida se relaciona con el tálamo, puede ocurrir el síndrome talámico. El objetivo de este relato de caso fue demostrar el uso de la electroacupuntura como coadyuvante en el tratamiento del dolor central, diagnosticado como síndrome talámico de difícil control con un tratamiento farmacológico.

Relato del caso: Paciente del sexo femenino, 46 años, con historial de accidente vascular encefálico isquémico, que le acometió la región temporoparietal izquierda en abril de 2003, evolucionando con hemiparesia y hemitaxia a la derecha. Después de un año, se inició el cuadro doloroso insidioso, continuo, difuso en el hemicuerpo derecho, seguido de alodínea e hiperalgesia, diagnosticado como síndrome talámico. En enero de 2006, se presentó en el servicio de terapia del dolor y medicina paliativa de la Santa Casa de Misericordia de São Paulo y empezó el tratamiento farmacológico con una mala respuesta, siendo programada para el abordaje en la neurofuncional. En julio de 2009, se le propuso el tratamiento con electroacupuntura en un intento de mejorar el control del cuadro álgico. Se realizaron sesiones de electroacupuntura en puntos en el cuero cabelludo y en los miembros. Después de la décima primera sesión, la paciente estaba con un cuadro álgico controlado, sin uso de opioides y amitriptilina tópica, una sensación de bienestar elevada, una mayor coordinación motora, y la disminución global del dolor verificada ya en la mano y la cara.

Conclusiones: La eficacia de la electroacupuntura en el control del cuadro álgico y en el aumento del bienestar, está a tono con los estudios modernos, que demuestran una activación de las vías antinociceptivas encefálicas por la electroacupuntura. Estudios clínicos prospectivos controlados son necesarios para reafirmar y consolidar la electroacupuntura como un importante instrumento en el control del dolor central.

Descriptores: ENFERMIDAD, Vascular: accidente cerebral vascular; DOLOR: Síndrome talámica; TÉCNICAS DE ANALGESIAS: acupuntura, eletroacupuntura. 